\title{
THE EFFECTS OF PITRESSIN ON THE METABOLISM AND EX- CRETION OF WATER AND ELECTROLYTES IN NORMAL SUBJECTS AND PATIENTS WITH CIRRHOSIS AND ASCITES 1, 2
}

\author{
By W. P. NELSON, III, 3,4 AND L. G. WELT \\ (From the Department of Internal Medicine, Yale University School of Medicine, \\ New Haven, Conn.)
}

(Submitted for publication November 23, 1951 ; accepted February 5, 1952)

\section{INTRODUCTION}

Salt and water are retained in nearly isotonic proportions in most edematous states. There is, however, a general tendency toward mild hypotonicity which is exaggerated when the salt intake is drastically reduced. This implies that there are forces operating to promote retention of water in excess of that which is secondary to the retention of salt. This primary retention of water may be due to 1) an antidiuretic stimulus other than hypertonicity of the body fluids, 2) an increased sensitivity to the normal amount of antidiuretic hormone, or 3) an increased quantity of circulating antidiuretic hormone related to improper inactivation or excretion of this substance (1-3).

Previous studies (4-6) suggested that certain patients with edema were more sensitive than normal subjects to the prolonged administration of Pitressin. The present investigation was designed to determine 1) whether patients with cirrhosis and ascites are more sensitive to endogenous or exogenous antidiuretic hormone, and 2) whether these patients are unable to inactivate or eliminate these substances normally. The question of an increased secretion of posterior pituitary or other antidiuretic substance is considered by inference. The excretion of electrolytes was measured during

1 Aided by an institutional grant and a research grant from the National Heart Institute, U. S. Public Health Service, and Contract V1001M-2300 of the Veterans Administration.

2 Presented in abstract form at the 43rd Annual Meeting of the American Society for Clinical Investigation, Atlantic City, N. J., April 30, 1951.

3 Work done during the tenure of a Life Insurance Medical Research Fellowship.

4 Present address : Dept. of Internal Medicine, Veterans Administration Hospital, Albany, New York. the onset of a water diuresis, during sudden Pitressin antidiuresis, and during resumption of the water diuresis.

\section{EXPERIMENTAL PROCEDURE AND METHODS}

Eight normal subjects and seven patients with cirrhosis of the liver and ascites were studied. Food and water were restricted for 10-14 hours prior to the experiment which was started about 8 a.m. Each study was conducted with the subject in the recumbent position and nothing by mouth was permitted. All urines were voided specimens. Samples of blood were collected under oil at the start of each study.

Following a control period of 30 to 60 minutes, an infusion of 5 per cent glucose in water was started and continued throughout the experiment. Approximately 1,000 cc. were administered during the first hour. Thereafter, the rate of administration of the infusate was adjusted to attain and maintain a positive balance of 1 liter of water. The volume of infusate administered during a given period approximated the volume of urine voided plus the insensible loss of water which was assumed to be $40 \mathrm{cc}$./ hr. This procedure promotes a relatively steady maximal rate of excretion of water due, presumably, to a continuous suppression of secretion of the antidiuretic hormone of the posterior pituitary gland. This may be regarded as a state of "physiological diabetes insipidus" (7).

After a steady maximal rate of excretion of water had been attained, Pitressin (Parke, Davis \& Company, Lot No. 161), in doses of $2.5,100$, or 2,000 milliunits, was administered. The two smaller doses were administered intravenously, the largest dose subcutaneously. The rate of infusion was reduced proportionately to the antidiuretic response to the Pitressin, and the experiment was continued until either the initial maximal rate of excretion of water was attained, or until it appeared evident that a maximal diuresis, though lower than the initial rate, had been achieved.

The "time" in Tables IV, V, and VI refers to the number of minutes in the pre-Pitressin period of the study, and the number of minutes following administration of Pitres$\sin$ in the second part of the study.

The chemical methods have been described in previous publications from this department $(8,9)$. 
TABLE I

The effects on excretion of water of a water load and administration of Pitressin in normal subjects and patients with cirrhosis and ascites

\begin{tabular}{|c|c|c|c|c|c|c|c|}
\hline & & $\begin{array}{c}\text { Time to } \\
\text { maximal } \\
\text { rate }\end{array}$ & $\underset{\text { rate }}{\text { Maximal }}$ & $\begin{array}{c}\text { Dose of } \\
\text { Pitressin }\end{array}$ & Minimum rate & $\begin{array}{c}\text { Reduction } \\
\text { in rate }\end{array}$ & $\begin{array}{l}\text { Time for } \\
\text { recovery }\end{array}$ \\
\hline \multirow{3}{*}{ Normal subjects } & $\begin{array}{l}\mathbf{P} \\
\text { Del } \\
\mathbf{S} \\
\mathbf{H}\end{array}$ & $\begin{array}{r}\min . \\
90 \\
122 \\
91 \\
72\end{array}$ & $\begin{array}{c}c c . / \min . \\
15.8 \\
7.9 \\
14.8 \\
14.1\end{array}$ & $\begin{array}{r}\text { milliunits } \\
2.5 \\
2.5 \\
2.5 \\
2.5\end{array}$ & $\begin{array}{c}c c . / \min . \\
7.9 \\
2.7 \\
3.4 \\
4.7\end{array}$ & $\begin{array}{c}\text { per cent } \\
50 \\
66 \\
77 \\
67\end{array}$ & $\begin{array}{c}\min . \\
88 \\
88 \\
88 \\
87\end{array}$ \\
\hline & $\begin{array}{l}\text { Co } \\
\text { V }\end{array}$ & $\begin{array}{l}83 \\
62\end{array}$ & $\begin{array}{l}15.6 \\
30.0\end{array}$ & $\begin{array}{l}100 . \\
100 .\end{array}$ & $\begin{array}{l}1.0 \\
4.3\end{array}$ & $\begin{array}{l}94 \\
86\end{array}$ & $\begin{array}{l}80 \\
59\end{array}$ \\
\hline & $\begin{array}{l}\text { Wa } \\
\text { O }\end{array}$ & $\begin{array}{l}88 \\
86\end{array}$ & $\begin{array}{l}24.4 \\
24.5\end{array}$ & $\begin{array}{l}2,000 \\
2,000\end{array}$ & $\begin{array}{l}0.9 \\
3.9\end{array}$ & $\begin{array}{l}96 \\
85\end{array}$ & $\begin{array}{l}355+ \\
273+\end{array}$ \\
\hline \multirow{3}{*}{$\begin{array}{l}\text { Patients with } \\
\text { cirrhosis }\end{array}$} & $\begin{array}{l}\mathrm{R} \\
\text { Des } \\
\text { Cr }\end{array}$ & $\begin{array}{l}65 \\
60 \\
90\end{array}$ & $\begin{array}{r}2.7 \\
23.8 \\
12.5\end{array}$ & $\begin{array}{l}2.5 \\
2.5 \\
2.5\end{array}$ & $\begin{array}{r}1.2 \\
10.4 \\
4.8\end{array}$ & $\begin{array}{l}86 \\
56 \\
74\end{array}$ & $\begin{array}{r}117 \\
54 \\
88\end{array}$ \\
\hline & $\begin{array}{l}\text { Wo } \\
\text { B }\end{array}$ & $\begin{array}{l}89 \\
75\end{array}$ & $\begin{array}{r}2.7 \\
21.7\end{array}$ & $\begin{array}{l}100 . \\
100 .\end{array}$ & $\begin{array}{l}0.5 \\
5.0\end{array}$ & $\begin{array}{l}81 \\
77\end{array}$ & $\begin{array}{l}86 \\
72\end{array}$ \\
\hline & $\begin{array}{l}\text { R } \\
\text { Dup }\end{array}$ & $\begin{array}{l}97 \\
95\end{array}$ & $\begin{array}{l}2.2 \\
7.5\end{array}$ & $\begin{array}{l}2,000 \\
2,000\end{array}$ & $\begin{array}{l}0.3 \\
0.3\end{array}$ & $\begin{array}{l}86 \\
96\end{array}$ & $?$ \\
\hline
\end{tabular}

RESULTS

The average time required to reach a maximal rate of excretion of water was 87 minutes in the eight normal subjects, and 82 minutes in the seven studies of patients with cirrhosis and ascites (Table I). The normal subjects achieved the maximal rate between 62 and 91 minutes except for one who took 122 minutes. However, the earliest time of a maximal diuresis in this subject was probably masked by the irregular collections of urine. The patients with cirrhosis reached maximal rates between 60 and 95 minutes.

TABLE II

The concentration of $\mathrm{Na}, \mathrm{K}$, and $\mathrm{Cl}$ in the serum of the normal subjects and patients with cirrhosis and ascites prior to the experiment

\begin{tabular}{|c|c|c|c|c|c|c|c|}
\hline \multicolumn{4}{|c|}{ Normal subjects } & \multicolumn{4}{|c|}{ Patients with cirrhosis } \\
\hline \multirow{2}{*}{ Subjects } & \multicolumn{3}{|c|}{$\begin{array}{l}\text { Conc. in serum } \\
(m E q . / L .)\end{array}$} & \multirow{2}{*}{ Subjects } & \multicolumn{3}{|c|}{$\begin{array}{l}\text { Conc. in serum } \\
(m E q . / L .)\end{array}$} \\
\hline & $\mathrm{Na}$ & $\mathbf{K}$ & $\mathbf{C l}$ & & $\mathrm{Na}$ & $\mathbf{K}$ & $\mathbf{C l}$ \\
\hline $\begin{array}{l}\mathbf{P} \\
\text { Del } \\
\text { S } \\
\mathbf{H} \\
\text { Co } \\
\mathrm{V} \\
\mathbf{W a} \\
\mathbf{O}\end{array}$ & \begin{tabular}{|l|}
141.5 \\
141.0 \\
139.3 \\
143.4 \\
137.5 \\
140.6 \\
141.2 \\
139.1
\end{tabular} & $\begin{array}{l}\frac{4.7}{4.5} \\
\frac{5.0}{5.0} \\
4.0 \\
4.8\end{array}$ & $\begin{array}{r}100.4 \\
99.1 \\
96.2 \\
100.7 \\
98.0 \\
100.4 \\
99.6 \\
96.8\end{array}$ & $\begin{array}{l}\text { R } \\
\text { Des } \\
\text { Cr } \\
\text { Wo } \\
\text { B } \\
\text { R } \\
\text { Dup }\end{array}$ & $\begin{array}{c}135.2 \\
136.7 \\
136.4 \\
132.3 \\
137.8 \\
\overline{131.8}\end{array}$ & $\begin{array}{l}4.1 \\
4.3 \\
3.8 \\
3.8 \\
4.4 \\
\frac{4.4}{4}\end{array}$ & $\begin{array}{r}95.5 \\
97.9 \\
97.4 \\
94.0 \\
104.8 \\
- \\
-\end{array}$ \\
\hline
\end{tabular}

The average maximal rate of excretion of water was $18.4 \mathrm{cc} . / \mathrm{min}$. in the normal subjects as compared with an average of $10.7 \mathrm{cc} . / \mathrm{min}$. in the cirrhotics. However, the individual maximal rates varied from 7.9 to $30.0 \mathrm{cc} . / \mathrm{min}$. in the normals, and from 2.2 to $23.8 \mathrm{cc}$. $/ \mathrm{min}$. in the cirrhotics. The three studies among the cirrhotics in which a maximum rate of excretion of water of less than $3 \mathrm{cc} / \mathrm{min}$. was achieved were on patients who excreted a urine that was virtually free of salt. There was no general relationship, however, between either 1) the maximal rate of excretion of salt and water, or 2) the initial rate of excretion of salt and the maximal rate of excretion of water attained.

\section{TABLE III}

The relationship between initial concentration of sodium in serum, the maximum rate of excretion of water, and the initial and maximum rates of excretion of sodium attained by patients with cirrhosis and ascites

\begin{tabular}{l|c|c|c|c}
\hline \hline Subject & $\begin{array}{c}\text { Conc. of Na } \\
\text { in serum }\end{array}$ & $\begin{array}{c}\text { Max. rate } \\
\text { excretion of } \\
\text { water }\end{array}$ & $\begin{array}{c}\text { Initial rate } \\
\text { excretion of } \\
\mathrm{Na}\end{array}$ & $\begin{array}{c}\text { Max. rate } \\
\text { excretion of } \\
\mathrm{Na}\end{array}$ \\
\hline & $\begin{array}{l}\text { mEq./L. } \\
\text { Dup }\end{array}$ & $\begin{array}{c}c c . / \text { min. } \\
\text { microEq./ } \\
\text { min. }\end{array}$ & $\begin{array}{c}\text { microEq./ } \\
\text { min. }\end{array}$ \\
Wo & 131.8 & 7.5 & 3.9 & 5.6 \\
R & 132.3 & 2.7 & 0.1 & 0.5 \\
Cr & 136.2 & 2.7 & 0.4 & 0.6 \\
Des & 136.7 & 12.5 & 14.0 & 76.0 \\
B & 137.8 & 23.8 & - & 148.0 \\
& & 21.7 & - & 191.0 \\
\hline
\end{tabular}


TABLE IV

The effects on the rates of excretion of water and electrolytes of 2.5 milliunits of Pitressin in normal subjects and patients with cirrhosis and ascites

\begin{tabular}{|c|c|c|c|c|c|c|c|c|c|c|c|}
\hline \multicolumn{6}{|c|}{ Normal subjects } & \multicolumn{6}{|c|}{ Patients with cirrhosis } \\
\hline \multirow{3}{*}{ Subject } & & \multicolumn{4}{|c|}{ Rates of excretion } & \multirow{3}{*}{ Subject } & \multirow{2}{*}{ Time } & \multicolumn{4}{|c|}{ Rates of excretion } \\
\hline & & $\mathrm{H}_{2} \mathrm{O}$ & $\mathrm{Na}$ & $\mathrm{Cl}$ & $\mathbf{K}$ & & & $\mathrm{H}_{2} \mathrm{O}$ & $\mathrm{Na}$ & $\mathrm{Cl}$ & $\mathbf{K}$ \\
\hline & $\min$. & $c c . / \min$. & & roEg./ & & & $\min$. & $c c . / \min$. & & $c r o E q . / n$ & \\
\hline \multirow{3}{*}{$\mathbf{P}$} & $\begin{array}{r}-0 \\
+60 \\
+90 \\
+123 \\
+150\end{array}$ & $\begin{array}{c}0.23 \\
1.7 \\
12.3 \\
15.8 \\
14.4\end{array}$ & $\begin{array}{r}9 \\
50 \\
167 \\
139 \\
94\end{array}$ & $\begin{array}{r}12 \\
56 \\
186 \\
145 \\
98\end{array}$ & $\begin{array}{l}17 \\
31 \\
92 \\
62 \\
42\end{array}$ & \multirow{3}{*}{$\mathbf{R}$} & $\begin{array}{r}-0 \\
+65 \\
+95 \\
+125 \\
+155\end{array}$ & $\begin{array}{l}0.07 \\
0.90 \\
2.7 \\
2.5 \\
2.6\end{array}$ & $\begin{array}{l}0 . \\
0.5 \\
0.6 \\
0.5 \\
0.4\end{array}$ & $\begin{array}{l}0.6 \\
2.6 \\
3.8 \\
5.5 \\
5.5\end{array}$ & $\begin{array}{r}0.3 \\
13.0 \\
23.0 \\
21.0 \\
20.0\end{array}$ \\
\hline & & & itress & & & & & & itressi & & \\
\hline & $\begin{array}{r}+58 \\
+88 \\
+119\end{array}$ & $\begin{array}{r}7.9 \\
10.5 \\
18.1\end{array}$ & $\begin{array}{r}104 \\
73 \\
110\end{array}$ & $\begin{array}{r}124 \\
84 \\
112\end{array}$ & $\begin{array}{l}45 \\
44 \\
56\end{array}$ & & $\begin{array}{r}+55 \\
+85 \\
+117 \\
+146 \\
+175\end{array}$ & $\begin{array}{l}1.3 \\
1.2 \\
1.3 \\
2.6 \\
2.4\end{array}$ & $\begin{array}{l}0.3 \\
0.3 \\
0.3 \\
0.4 \\
0.4\end{array}$ & $\begin{array}{l}4.0 \\
4.1 \\
4.3 \\
5.7 \\
5.8\end{array}$ & $\begin{array}{l}15.0 \\
18.0 \\
20.0 \\
23.0 \\
22.0\end{array}$ \\
\hline \multirow{3}{*}{ Del } & $\begin{array}{r}-0 \\
+92 \\
+122 \\
+152 \\
+182 \\
+212\end{array}$ & $\begin{array}{l}0.5 \\
1.0 \\
5.8 \\
7.9 \\
7.1 \\
6.9\end{array}$ & $\begin{array}{r}\overline{74} \\
234 \\
256 \\
181 \\
160\end{array}$ & $\begin{array}{r}79 \\
75 \\
236 \\
255 \\
187 \\
165\end{array}$ & $\begin{array}{l}36 \\
24 \\
48 \\
38 \\
26 \\
26\end{array}$ & \multirow{3}{*}{ Des } & $\begin{array}{r}-0 \\
+60 \\
+85 \\
+115 \\
+148\end{array}$ & $\begin{array}{r}\overline{2.2} \\
23.4 \\
19.3 \\
23.8\end{array}$ & $\begin{array}{r}\overline{29.0} \\
122.0 \\
137.0 \\
148.0\end{array}$ & $\begin{array}{r}\overline{39.0} \\
131.0 \\
172.0 \\
188.0\end{array}$ & $\begin{array}{l}-\overline{34.0} \\
44.0 \\
60.0 \\
67.0\end{array}$ \\
\hline & \multicolumn{5}{|c|}{ Pitressin } & & \multicolumn{5}{|c|}{ Pitressin } \\
\hline & $\begin{array}{r}+88 \\
+118 \\
+148\end{array}$ & $\begin{array}{l}2.7 \\
6.0 \\
5.7\end{array}$ & $\begin{array}{l}123 \\
164 \\
181\end{array}$ & $\begin{array}{l}142 \\
170 \\
182\end{array}$ & $\begin{array}{l}24 \\
23 \\
19\end{array}$ & & $\begin{array}{r}+26 \\
+54 \\
+86 \\
+116 \\
+141\end{array}$ & $\begin{array}{l}15.7 \\
10.4 \\
23.6 \\
16.7 \\
13.0\end{array}$ & $\begin{array}{r}121.0 \\
71.0 \\
73.0 \\
37.0 \\
39.0\end{array}$ & $\begin{array}{r}174.0 \\
123.0 \\
113.0 \\
73.0 \\
87.0\end{array}$ & $\begin{array}{l}64.0 \\
47.0 \\
40.0 \\
37.0 \\
36.0\end{array}$ \\
\hline \multirow[t]{3}{*}{$\mathbf{S}$} & $\begin{array}{r}-0 \\
+60 \\
+91 \\
+120 \\
+151\end{array}$ & $\begin{array}{c}0.30 \\
1.4 \\
9.7 \\
14.7 \\
14.8\end{array}$ & $\begin{array}{r}42 \\
109 \\
163 \\
160 \\
139\end{array}$ & $\begin{array}{r}65 \\
135 \\
191 \\
166 \\
139\end{array}$ & $\begin{array}{l}35 \\
53 \\
58 \\
49 \\
46\end{array}$ & \multirow{3}{*}{$\mathrm{Cr}$} & $\begin{array}{r}-0 \\
+60 \\
+90 \\
+120 \\
+150 \\
+180\end{array}$ & $\begin{array}{l}0.46 \\
0.38 \\
8.8 \\
11.7 \\
12.5 \\
11.8\end{array}$ & $\begin{array}{r}14.0 \\
5.0 \\
66.0 \\
76.0 \\
71.0 \\
71.0\end{array}$ & $\begin{array}{r}27.0 \\
13.0 \\
113.0 \\
112.0 \\
115.0 \\
119.0\end{array}$ & $\begin{array}{l}19.0 \\
14.0 \\
65.0 \\
50.0 \\
53.0 \\
53.0\end{array}$ \\
\hline & \multicolumn{5}{|c|}{ Pitressin } & & \multicolumn{5}{|c|}{ Pitressin } \\
\hline & $\begin{array}{r}+57 \\
+88 \\
+117\end{array}$ & $\begin{array}{r}3.4 \\
11.8 \\
13.3\end{array}$ & $\begin{array}{l}86 \\
97 \\
97\end{array}$ & $\begin{array}{r}112 \\
107 \\
93\end{array}$ & $\begin{array}{l}35 \\
35 \\
31\end{array}$ & & $\begin{array}{r}+63 \\
+88 \\
+118\end{array}$ & $\begin{array}{r}4.8 \\
7.8 \\
12.2\end{array}$ & $\begin{array}{l}36.0 \\
14.0 \\
43.0\end{array}$ & $\begin{array}{l}72.0 \\
47.0 \\
79.0\end{array}$ & $\begin{array}{l}36.0 \\
31.0 \\
47.0\end{array}$ \\
\hline \multirow{3}{*}{$\mathbf{H}$} & $\begin{array}{r}-0 \\
+72 \\
+102 \\
+132 \\
+162 \\
+192\end{array}$ & $\begin{array}{r}0.6 \\
6.4 \\
14.1 \\
12.5 \\
12.8 \\
13.6\end{array}$ & $\begin{array}{l}64 \\
63 \\
78 \\
55 \\
64 \\
73\end{array}$ & $\begin{array}{l}79 \\
82 \\
72 \\
41 \\
40 \\
46\end{array}$ & $\begin{array}{r}52 \\
100 \\
127 \\
84 \\
67 \\
54\end{array}$ & & & & & & \\
\hline & \multicolumn{5}{|c|}{ Pitressin } & & & & & & \\
\hline & $\begin{array}{r}+57 \\
+87 \\
+117 \\
+147\end{array}$ & $\begin{array}{r}4.7 \\
9.4 \\
11.0 \\
9.8\end{array}$ & $\begin{array}{l}55 \\
55 \\
50 \\
53\end{array}$ & $\begin{array}{l}41 \\
24 \\
19 \\
24\end{array}$ & $\begin{array}{l}22 \\
39 \\
24 \\
25\end{array}$ & & & & & & \\
\hline
\end{tabular}


However, in addition to the fact that the average concentration of sodium in the serum (Table II) was lower in the group of cirrhotics than in the normal subjects, there was an excellent correlation among the cirrhotics between this concentration and the maximal rate of excretion of water (Table III). The patients with the lowest concentrations of sodium in the serum excreted little salt and developed low maximal rates of excretion of water. These correlations were not evident in the group of normal subjects.

Two and a half milliunits of Pitressin reduced the average rate of flow of urine by 65 per cent in the four normal subjects and 72 per cent in the three patients with cirrhosis. The administration of 100 milliunits of Pitressin was followed by a 90 per cent reduction of urine flow in two normals as compared with 79 per cent in two cir- rhotics. Two thousand milliunits of Pitressin administered subcutaneously reduced the rate of flow of urine by 90 and 91 per cent in two normal subjects and two patients with cirrhosis respectively (Table I).

The average time for recovery to a maximal rate of excretion of water following administration of 2.5 milliunits of Pitressin was 88 and 86 minutes in the normals and cirrhotics, respectively ; following 100 milliunits it was 70 and 79 minutes. It will be noted that one each, of the normal subjects (Co) and of the patients with cirrhosis (B), failed to attain the pre-Pitressin maximal rate of excretion of water after the dose of 100 milliunits. However, they had both clearly recovered from the antidiuretic effect. Clear-cut early recovery was apparent in 232 minutes in the normal subjects following the subcutaneous administration of 2,000

TABLE V

The effects on the rates of excretion of water and electrolytes of 100 milliunits of Pitressin in normal subjects and patients with cirrhosis and ascites

\begin{tabular}{|c|c|c|c|c|c|c|c|c|c|c|c|}
\hline \multicolumn{6}{|c|}{ Normal subjects } & \multicolumn{6}{|c|}{ Patients with cirrhosis } \\
\hline \multirow{3}{*}{ Subject } & \multirow{3}{*}{$\begin{array}{c}\text { Time } \\
\text { min. }\end{array}$} & \multicolumn{4}{|c|}{ Rates of excretion } & \multirow{3}{*}{ Subject } & \multirow{2}{*}{ Time } & \multicolumn{4}{|c|}{ Rates of excretion } \\
\hline & & $\mathrm{H}_{2} \mathrm{O}$ & $\mathbf{N a}$ & $\mathrm{Cl}$ & $\mathbf{k}$ & & & $\mathrm{H}_{5} \mathrm{O}$ & $\mathrm{Na}$ & $\mathbf{C l}$ & $\mathbf{K}$ \\
\hline & & $c c . / m i n$. & & roEq./ & & & $\min$. & cc./min. & & roE $q . / m i$ & \\
\hline \multirow{3}{*}{ Co } & $\begin{array}{r}-0 \\
+83 \\
+118 \\
+148\end{array}$ & $\begin{array}{r}\overline{4.9} \\
15.6 \\
15.6\end{array}$ & $\begin{array}{l}\overline{44} \\
98 \\
95\end{array}$ & $\begin{array}{l}\overline{137} \\
115 \\
107\end{array}$ & $\begin{array}{r}-102 \\
55 \\
48\end{array}$ & \multirow{3}{*}{ Wo } & $\begin{array}{r}-0 \\
+30 \\
+59 \\
+89 \\
+119 \\
+149 \\
+180\end{array}$ & $\begin{array}{l}0.28 \\
0.39 \\
1.1 \\
1.8 \\
2.7 \\
1.7 \\
0.97\end{array}$ & $\begin{array}{l}0.1 \\
0.2 \\
0.5 \\
0.5 \\
0.4 \\
0.3 \\
0.3\end{array}$ & $\begin{array}{l}0.8 \\
0.9 \\
1.9 \\
2.5 \\
4.2 \\
3.2 \\
2.3\end{array}$ & $\begin{array}{l}20 \\
25 \\
48 \\
41 \\
32 \\
25 \\
18\end{array}$ \\
\hline & \multicolumn{5}{|c|}{ Pitressin } & & \multicolumn{5}{|c|}{ Pitressin } \\
\hline & $\begin{array}{r}+80 \\
+116 \\
+146 \\
+176\end{array}$ & $\begin{array}{l}1.0 \\
7.7 \\
7.5 \\
6.8\end{array}$ & $\begin{array}{l}26 \\
62 \\
34 \\
34\end{array}$ & $\begin{array}{r}49 \\
121 \\
40 \\
29\end{array}$ & $\begin{array}{l}27 \\
83 \\
46 \\
31\end{array}$ & & $\begin{array}{r}+56 \\
+86 \\
+116 \\
+146\end{array}$ & $\begin{array}{l}0.54 \\
1.8 \\
2.7 \\
2.2\end{array}$ & $\begin{array}{l}0.2 \\
0.3 \\
0.3 \\
0.3\end{array}$ & $\begin{array}{l}2.5 \\
3.4 \\
4.6 \\
4.5\end{array}$ & $\begin{array}{l}16 \\
20 \\
20 \\
17\end{array}$ \\
\hline \multirow{3}{*}{ v } & $\begin{array}{r}-0 \\
+62 \\
+86 \\
+106 \\
+127\end{array}$ & $\begin{array}{c}0.81 \\
2.3 \\
30.0 \\
12.0 \\
25.2\end{array}$ & $\begin{array}{r}190 \\
57 \\
432 \\
106 \\
219\end{array}$ & $\begin{array}{r}207 \\
58 \\
390 \\
84 \\
159\end{array}$ & $\begin{array}{r}64 \\
27 \\
162 \\
18 \\
33\end{array}$ & \multirow{3}{*}{ B } & $\begin{array}{r}-0 \\
+60 \\
+75 \\
+90 \\
+105\end{array}$ & $\begin{array}{r}\overline{1.2} \\
12.3 \\
21.7 \\
18.3\end{array}$ & $\begin{array}{r}\overline{31.0} \\
177.0 \\
191.0 \\
134.0\end{array}$ & $\begin{array}{r}\overline{19.0} \\
107.0 \\
100.0 \\
78.0\end{array}$ & $\begin{array}{r}\overline{33} \\
150 \\
104 \\
44\end{array}$ \\
\hline & & & itressi & & & & \multicolumn{5}{|c|}{ Pitressin } \\
\hline & $\begin{array}{r}+59 \\
+80 \\
+101\end{array}$ & $\begin{array}{r}4.3 \\
21.2 \\
21.2\end{array}$ & $\begin{array}{l}103 \\
265 \\
151\end{array}$ & $\begin{array}{l}113 \\
268 \\
123\end{array}$ & $\begin{array}{l}21 \\
61 \\
30\end{array}$ & & $\begin{array}{r}+17 \\
+72 \\
+106 \\
+143 \\
+183\end{array}$ & $\begin{array}{r}10.0 \\
5.0 \\
8.4 \\
7.3 \\
9.2\end{array}$ & $\begin{array}{r}116.0 \\
33.0 \\
27.0 \\
26.0 \\
34.0\end{array}$ & $\begin{array}{l}91.0 \\
27.0 \\
23.0 \\
16.0 \\
14.0\end{array}$ & $\begin{array}{l}51 \\
30 \\
37 \\
30 \\
33\end{array}$ \\
\hline
\end{tabular}


TABLE VI

The effects on the rates of excretion of water and electrolytes of 2,000 milliunits of Pitressin in normal subjects and patients with cirrhosis and ascites

\begin{tabular}{|c|c|c|c|c|c|c|c|c|c|c|c|}
\hline \multicolumn{6}{|c|}{ Normal subjects } & \multicolumn{6}{|c|}{ Patients with cirrhosis } \\
\hline \multirow{3}{*}{ Subject } & \multirow{2}{*}{ Time } & \multicolumn{4}{|c|}{ Rates of excretion } & \multirow{2}{*}{ Subject } & \multirow{2}{*}{ Time } & \multicolumn{4}{|c|}{ Rates of excretion } \\
\hline & & $\mathrm{H}_{2} \mathrm{O}$ & $\mathbf{N a}$ & $\mathrm{Cl}$ & $\mathbf{K}$ & & & $\mathrm{H}_{2} \mathrm{O}$ & $\mathbf{N a}$ & $\mathrm{Cl}$ & $\mathbf{K}$ \\
\hline & $\min$. & $c c . / m i n$. & \multicolumn{3}{|c|}{ microEq./min. } & & min. & $c c . / m i n$. & \multicolumn{3}{|c|}{ microEq./min. } \\
\hline \multirow{3}{*}{$\mathrm{Wa}$} & $\begin{array}{r}-0 \\
+54 \\
+88 \\
+115 \\
+142\end{array}$ & $\begin{array}{c}0.75 \\
1.7 \\
15.3 \\
24.4 \\
23.7\end{array}$ & $\begin{array}{l}111 \\
120 \\
167 \\
305 \\
360\end{array}$ & $\begin{array}{l}134 \\
142 \\
178 \\
266 \\
341\end{array}$ & $\begin{array}{l}68 \\
84 \\
80 \\
73 \\
50\end{array}$ & \multirow{3}{*}{ A } & $\begin{array}{r}-0 \\
+62 \\
+97 \\
+127 \\
+157 \\
+189 \\
+217\end{array}$ & $\begin{array}{l}0.33 \\
0.48 \\
1.2 \\
1.6 \\
1.8 \\
2.2 \\
1.5\end{array}$ & $\begin{array}{l}0.4 \\
0.4 \\
0.5 \\
0.5 \\
0.5 \\
0.6 \\
0.5\end{array}$ & $\begin{array}{l}1.5 \\
1.0 \\
2.6 \\
2.1 \\
3.6 \\
3.7 \\
4.5\end{array}$ & $\begin{array}{l}24 \\
21 \\
23 \\
20 \\
19 \\
20 \\
20\end{array}$ \\
\hline & & & itressi & & & & \multicolumn{5}{|c|}{ Pitressin } \\
\hline & $\begin{array}{r}+37 \\
+227 \\
+300 \\
+330 \\
+355\end{array}$ & $\begin{array}{c}11.8 \\
0.92 \\
3.6 \\
9.0 \\
11.4\end{array}$ & $\begin{array}{l}264 \\
143 \\
120 \\
140 \\
164\end{array}$ & $\begin{array}{r}250 \\
141 \\
128 \\
106 \\
98\end{array}$ & $\begin{array}{l}38 \\
27 \\
22 \\
23 \\
22\end{array}$ & & $\begin{array}{r}+57 \\
+87 \\
+150 \\
+210 \\
+271\end{array}$ & $\begin{array}{l}0.47 \\
0.43 \\
0.34 \\
0.37 \\
0.38\end{array}$ & $\begin{array}{l}0.3 \\
0.4 \\
0.3 \\
0.3 \\
0.3\end{array}$ & $\begin{array}{l}2.0 \\
1.9 \\
1.4 \\
1.7 \\
1.9\end{array}$ & $\begin{array}{l}19 \\
22 \\
16 \\
13 \\
11\end{array}$ \\
\hline \multirow{3}{*}{0} & $\begin{array}{r}-0 \\
+86 \\
+110 \\
+130 \\
+142 \\
+163\end{array}$ & $\begin{array}{c}0.38 \\
3.7 \\
18.2 \\
19.7 \\
23.5 \\
24.5\end{array}$ & $\begin{array}{r}42 \\
68 \\
144 \\
116 \\
153 \\
150\end{array}$ & $\begin{array}{r}81 \\
73 \\
159 \\
115 \\
121 \\
143\end{array}$ & $\begin{array}{l}66 \\
37 \\
69 \\
39 \\
40 \\
32\end{array}$ & \multirow{3}{*}{ Dup } & $\begin{array}{r}-0 \\
+65 \\
+95 \\
+125 \\
+155\end{array}$ & $\begin{array}{l}0.43 \\
0.78 \\
4.5 \\
7.5 \\
5.0\end{array}$ & $\begin{array}{l}3.9 \\
4.6 \\
4.0 \\
5.6 \\
3.7\end{array}$ & $\begin{array}{l}11.0 \\
10.0 \\
13.0 \\
20.0 \\
20.0\end{array}$ & $\begin{array}{l}51 \\
48 \\
30 \\
33 \\
29\end{array}$ \\
\hline & & & itress & & & & \multicolumn{5}{|c|}{ Pitressin } \\
\hline & $\begin{array}{r}+62 \\
+187 \\
+232 \\
+256 \\
+273\end{array}$ & $\begin{array}{r}6.5 \\
3.6 \\
10.2 \\
16.7 \\
20.9\end{array}$ & $\begin{array}{r}137 \\
62 \\
70 \\
108 \\
123\end{array}$ & $\begin{array}{r}146 \\
73 \\
73 \\
71 \\
72\end{array}$ & $\begin{array}{l}56 \\
40 \\
48 \\
35 \\
31\end{array}$ & & $\begin{array}{r}+60 \\
+150 \\
+260 \\
+300 \\
+330\end{array}$ & $\begin{array}{l}1.6 \\
0.33 \\
0.36 \\
0.38 \\
0.33\end{array}$ & $\begin{array}{l}2.1 \\
1.7 \\
1.2 \\
1.2 \\
0.9\end{array}$ & $\begin{array}{r}10.0 \\
7.0 \\
5.0 \\
4.0 \\
2.0\end{array}$ & $\begin{array}{l}18 \\
16 \\
14 \\
14 \\
10\end{array}$ \\
\hline
\end{tabular}

milliunits. In contrast, there was no evidence of recovery up to 271 and 330 minutes in the two cirrhotic patients who received this dose of Pitressin (Tables I, IV, V, and VI).

The rate of excretion of sodium and chloride increased sharply during the ascent of the initial diuresis in every experiment on a normal subject except for $\mathrm{H}$ (Tables IV, V, and VI). Although there was a tendency for the rates of excretion of these ions to increase in the patients with cirrhosis and ascites, this was unimpressive except in the studies on B and Cr. An increase in the rate of excretion of potassium was evident in almost every experiment, but the change was not striking. The antidiuretic period following the injection of Pitressin was characterized by a decrease in the rates of excretion of sodium and chloride in every subject, both normal and cirrhotic, except $\mathrm{P}$. The rates of excretion of potassium decreased in most instances, but, again, these changes were small. In no instance in the post-Pitressin period did the rate of excretion of any of the three ions exceed the highest rate in the foreperiod.

The rates of excretion of these electrolytes remained the same or increased to a minor degree when the rate of excretion of water increased as the effect of Pitressin diminished. This is in sharp contrast to the augmented rates of excretion of salt during the development of the initial diuresis.

Glucosuria occurred commonly during the initial stages of the water diuresis in these studies. However, this was quantitatively insignificant and disappeared as the experiment progressed. 


\section{DISCUSSION}

A decrease in the effective osmotic pressure of the body fluids promotes a graded suppression of the rate of secretion of antidiuretic hormone by the posterior pituitary gland; and this, of course, is associated with a reduction in the reabsorption of water in the distal tubules resulting in an augmented rate of excretion of water (7). This, however, is not limitless; beyond a certain degree of dilution of the body fluids a further increase in the positive balance of water will not promote a greater rate of excretion (10). The interval between the induction of adequate dilution of the body fluids and the attainment of the maximal rate of excretion of water represents the time necessary to inactivate or eliminate the circulating antidiuretic hormone. The fact that the average time required to attain a maximal rate of excretion of water did not differ in these two groups of subjects implies that patients with cirrhosis and ascites have no deficiency with respect to the inactivation or elimination of that antidiuretic hormone whose secretion is suppressed by dilution of the body fluids. The degree of antidiuresis induced by a particular dose of Pitressin was the same in each group. This can only mean that the cells of the distal tubules of the kidneys of patients with cirrhosis and ascites are not more sensitive to a given level of circulating Pitressin. The rates of recovery from the Pitressin antidiuresis were the same in the two groups when doses of Pitressin that may be considered within the physiological range were administered (11). Essentially similar results have been reported by White, Rubin, and Leiter (12). There was, however, a distinct delay in recovery in the two subjects with cirrhosis when the largest dose (2,000 milliunits) was administered. It may be concluded, therefore, that the cirrhotic is able to inactivate or eliminate exogenously administered antidiuretic hormone in doses within physiological limits.

There remain two distinct differences between the two groups of subjects: 1 ) the lower maximal rate of excretion of water, and 2) a delayed recovery from the antidiuresis induced by a large dose of Pitressin. It was mentioned in the preceding section that the concentration of sodium in the serum was lower in the patients with cirrhosis, and, in this group, there was a clear correlation between the lower concentration of this ion in the serum and a low maximal rate of excretion of water. It is most probable in this instance that the depressed concentration of sodium in the serum is a result and not the cause of an inability to excrete water at a normal rate. It may be highly relevant, however, that the patients with extremely depressed rates of excretion of salt were the same who exhibited low maximal rates of diuresis. It suggests the possibility that both the antisaluresis and antidiuresis derive from a common stimulus.

The evidence is clear (1-3) that a contracted plasma volume, or some function thereof, serves as a stimulus to promote an increased reabsorption of salt by the renal tubules. Moreover, there is a considerable body of data to support the contention that a contracted volume may promote a retention of water in excess of that which is related to the increased reabsorption of salt. The precise mechanism of the antidiuresis associated with a contracted plasma volume is not clear, but the evidence at this time is most compatible with the hypothesis that the contracted volume promotes the secretion of the antidiuretic hormone of the posterior pituitary gland (13-17).

A progressive increase in the volume of an ascitic collection implies that fluid is transuding from the blood stream more rapidly than it is reabsorbed. This presents the stimulus of a contracted plasma volume which may be responsible for both the antisaluresis and antidiuresis seen among some of these patients with cirrhosis and ascites. When the body fluids of the patient with cirrhosis are diluted by the production of a positive water balance, secretion of the hormone of the posterior pituitary gland will not be completely suppressed since this procedure does not modify the contracted plasma volume which remains as a persistent stimulus for secretion of antidiuretic hormone. Thus, although this patient will have no delay in achieving a maximal diuresis, the magnitude of this diuresis will be less than normal in proportion to the intensity of the stimulus provided by the contracted plasma volume.

A delay in recovery from the antidiuresis provoked by the administration of Pitressin must be interpreted to mean that an effective antidiuretic concentration of this hormone has been maintained for a longer time. It is clear that there is such a delay in recovery in the normal subjects who re- 
ceived the dose of 2,000 milliunits compared with other normals who received much smaller doses. This may be related both to the size of the dose and the different route of administration. The large dose and slower access to the circulation may provide an adequate antidiuretic concentration for a longer period of time. The rate of reabsorption from a subcutaneous depot may well be slower in a patient with hypoalbuminemia and this may account for the greater delay in recovery by the cirrhotics.

Several alternative suggestions to explain this difference may be offered. When Pitressin is administered to a normal subject with suppression of secretion of antidiuretic hormone induced by hypotonicity of the body fluids, the mechanisms involved in the inactivation or excretion of this hormone are completely unsaturated. This is not the case in the cirrhotic with ascites if the contracted plasma volume has not been corrected. It may be that partial saturation of the mechanisms involved in elimination of antidiuretic hormone may make it more difficult to eliminate completely such a large dose.

It has been alternatively suggested that the diseased liver is deficient with respect to inactivation of antidiuretic hormone, and that the increased quantities of antidiuretic substance and consequent ascites are related to this dysfunction (18-20). However, the degree of liver disease and ascites formation are not necessarily well correlated. Moreover, the retention of salt and water may be mitigated if a communication is made between the ascitic cavity and subcutaneous tissue of a patient with cirrhosis and ascites (21-23). There is no evidence that this procedure modifies the disease in the liver. In addition, there appears to be a similar abnormal response to administered posterior pituitary substance in patients with congestive heart failure and the nephrotic syndrome (5). There would, therefore, appear to be very little reason to indict the diseased liver per se for this delay in recovery from the antidiuresis.

The administration of Pitressin did not promote an increase in the rate of excretion of sodium, chloride, or potassium in either group. In most instances there were no changes or minimal decreases in these rates of excretion. A similar lack of effect of Pitressin on the rates of excretion of electrolytes has been reported by others $(12,24$,
25). The sharp increase in the rates of excretion of sodium and chloride with the ascent of the initial diuresis, and the almost complete absence of this response during the development of the postPitressin diuresis deserve consideration. There are numerous reports of an increase in the rate of excretion of salt associated with the onset of a water diuresis. This has most frequently been interpreted to represent an effect of the increasing urine flow per se. Crutchfield and Wood (26) made the interesting observation that the acceleration in the rate of excretion of salt associated with a water diuresis was inversely correlated with the rate of urine flow prior to the administration of the load of water. It is well recognized that there is an increased tubular reabsorption of sodium chloride in water deprivation. The rate of excretion of sodium may be quite low in patients suffering with severe deficits of water despite the fact that the concentration of sodium in the serum is distinctly elevated. This has been called the "dehydration reaction" $(9,27)$. It would, therefore, be anticipated that the state of hydropenia should be characterized by some increase in the renal tubular reabsorption of salt. The administration of a load of water corrects the hydropenic state which would be expected to suppress the stimulus favoring the reabsorption of salt and promote an increase in its rate of excretion. Later in the course of the diuresis the excretion of salt diminishes which may be related to a decrease in the concentration of sodium and chloride in the serum. From the time of the administration of Pitressin to the end of the study the positive balance of water was maintained at a reasonably constant level. Therefore, under these circumstances the post-Pitressin diuresis developed at a time when hydration was more than adequate and was unchanging. This second diuresis was not associated with a relief from dehydration; there was no alteration that would modify salt reabsorption, and therefore, there was little or no increase in its rate of excretion.

\section{SUMMARY AND CONCLUSIONS}

1. Normal subjects and patients with cirrhosis and ascites did not differ $a$ ) in the time required to achieve a maximal rate of diuresis in response to the administration of a water load, or $b$ ) in the intensity or duration of the antidiuresis promoted 
by a dose of 2.5 or 100 milliunits of Pitressin. It is therefore concluded that the patient with cirrhosis and ascites displays no evidence of an increased sensitivity to or an inability to eliminate or inactivate endogenous or physiologic doses of exogenous posterior pituitary hormone.

2. The rate of maximal diuresis was quite low in some of the patients with cirrhosis and ascites. This was associated with a markedly depressed rate of excretion of salt. Since a contracted plasma volume may promote the secretion of antidiuretic hormone and salt retention, it is suggested that this single stimulus may be responsible for the depression of both rates of excretion.

3. The cause of the delayed recovery from the antidiuresis following the largest dose of Pitressin in the cirrhotic may be explained by a slower rate of absorption of the hormone from the subcutaneous tissues into the circulation. This might allow a longer interval during which an adequate antidiuretic concentration obtained. Alternative suggestions are offered.

4. The administration of Pitressin did not promote the excretion of sodium chloride.

5. The rates of excretion of sodium and chloride increased significantly during the initial period of the diuresis in the normal subjects. However, there were little or no changes in these rates during the diureses following recovery from the Pitressin. The administration of the water load corrected the deficit of the hydropenic state initially, thus suppressing a stimulus favoring a low rate of excretion of salt. Since there were no alterations in the volume or tonicity of the body fluids throughout the remainder of the study, there were no significant influences that would tend to modify the rate of excretion of salt.

\section{ACKNOWLEDGMENT}

The authors are indebted to Jane V. Lee, A.B., and Gloria E. Nassif, A.B., for their aid in these studies.

\section{REFERENCES}

1. Peters, J. P., The role of sodium in the production of edema. New England J. Med., 1948, 239, 353.

2. Welt, L. G., and Seldin, D. W., The pathologic physiology and treatment of edema. V. A. Tech. Bull., Jan. 12, 1951, TB $10-69$.

3. Peters, J. P., Sodium, water, and edema. J. Mt. Sinai Hosp., 1950, 17, 159.
4. Lloyd, C. W., Harris, J. F., and Lobetsky, J., Some studies of posterior pituitary and adrenal cortical interrelationships. J. Clin. Invest., 1951, 30, 657.

5. Welt, L. G., Seldin, D. W., and Cort, J. H., The effects of the pituitary and adrenal hormones on the metabolism and excretion of sodium and water. J. Clin. Invest., 1951, 30, 682.

6. Welt, L. G., and Seldin, D. W., The effects of the chronic administration of Pitressin in normals and patients with cirrhosis and ascites. In preparation.

7. Verney, E. B., Croonian lecture; The antidiuretic hormone and the factors which determine its release. Proc. Roy. Soc. London, 1947, s.B., 135, 25.

8. Hald, P. M., The flame photometer for the measurement of sodium and potassium in biological materials. J. Biol. Chem., 1947, 167, 499.

9. Elkinton, J. R., and Taffel, M., Prolonged water deprivation in the dog. J. Clin. Invest., 1942, 21, 787.

10. Welt, L. G., and Nelson, W. P., III, Observations on the excretion of water. J. Applied Physiol., in press.

11. Lauson, H. D., The problem of estimating the rate of secretion of antidiuretic hormone in man. Am. J. Med., 1951, 11, 135.

12. White, A. G., Rubin, G., and Leiter, L., Studies in edema. III. The effect of Pitressin on the renal excretion of water and electrolytes in patients with and without liver disease. J. Clin. Invest., 1951, 30, 1287.

13. Martin, S. J., Herrlich, H. C., and Fazekas, J. F., Relation between electrolyte imbalance and excretion of an antidiuretic substance in adrenalectomized cats. Am. J. Physiol., 1939, 127, 51.

14. Leaf, A., and Mamby, A. R., An antidiuretic mechanism not regulated by extracellular fluid tonicity. J. Clin. Invest., 1951, 30, 654 ; 1952, 31, 60.

15. Brun, C., Knudsen, E. O. E., and Raaschou, F., The influence of posture on the kidney function. I. The fall of the diuresis in the erect posture; II. Glomerular dynamics in the passive erect posture. Acta med. Scandinav., 1945, 122, $315 ; 332$.

16. Welt, L. G., and Orloff, J., The effects of an increase in plasma volume on the metabolism and excretion of water and electrolytes by normal subjects. J. Clin. Invest., 1951, 30, 751.

17. Judson, W. E., Epstein, F. H., Tinsley, C. M., Burrows, B. A., and Wilkins, R. W., The hemodynamic and renal functional effects of venous congestion of the limbs in patients with diabetes insipidus. J. Clin. Invest., 1950, 29, 826.

18. Ralli, E. P., Robson, J. S., Clarke, D., and Hoagland, C. L., Factors influencing ascites in patients with cirrhosis of the liver. J. Clin. Invest., 1945, 24, 316.

19. Heller, H., and Urban, F. F., The fate of antidiuretic principle of post-pituitary extracts in vivo and in vitro. J. Physiol., 1935, 85, 502.

20. Eversole, W. J., Birnie, J. H., and Gaunt, R., Inactivation of posterior pituitary antidiuretic hormone by the liver. J. Clin. Endocrinol., 1948, 8, 616. 
21. Peters, J. P., The problem of cardiac edema. Am. J. Med., 1952, 12, 66.

22. Crosby, R. C., and Cooney, E. A., Surgical treatment of ascites. New England J. Med., 1946, 235, 581.

23. Parker, M. L., and Breckler, I. A., Contribution to the surgical treatment of ascites. Modification of the Crosby-Cooney technique. J. A. M. A., 1950, 144, 1091.

24. Murphy, R. J. F., and Stead, E. A., Jr., Effects of exogenous and endogenous posterior pituitary antidiuretic hormone on water and electrolyte excretion. J. Clin. Invest., 1951, 30, 1055.
25. Chalmers, T. M., Lewis, A. A. G., and Pawan, G. L. S., Effect of posterior pituitary extracts on the renal excretion of sodium and chloride in man. J. Physiol., 1951, 112, 238.

26. Crutchfield, A. J., Jr., and Wood, J. E., Jr., Urine volume and total renal sodium excretion during water diuresis. Ann. Int. Med., 1948, 28, 28.

27. Winkler, A. W., Danowski, T. S., Elkinton, J. R., and Peters, J. P., Electrolyte and fluid studies during water deprivation and starvation in human subjects, and effect of ingestion of fish, of carbohydrate, and of salt solutions. J. Clin. Invest., 1944, 23, 807. 